\title{
Como (ainda) ser feliz na profissão
}

A pós quatro décadas de tranquilo exercício da oftalmologia julgo-me autorizado a tentar compartilhar algumas idéias de como ainda é possível ser feliz como médico. A mensagem destina-se principalmente aos mais jovens.

Vivemos tempos de materialismo exaltado e de aparências. Para Gilles Lipovetsky, filósofo francês contemporâneo, no pós-modernismo a “imagem" domina a realidade. Ser alguém é aparecer na tela e no website. Aquilo que é visto define o que deve ser; quase ninguém mais se importa com o que é realidade. A imagem pública é o objeto de culto.

Múltiplas instituições vivem atualmente uma crise de credibilidade. As pessoas deixam de crer em sua seriedade. Isso se reflete na economia, na política e também, é óbvio, na vida diária de cada um. A Medicina não ficou imune à descrença. Tanto as crises econômica e política quanto a médica podem ser atribuídas a uma outra muito maior e pouco comentada - a crise ética.

Não é objetivo deste trabalho discutir o que é ética, já que podemos simplificar o conceito com uma frase milenar: "Não faças aos outros aquilo que não queres que te façam". O egocentrismo, o individualismo e a indiferença por conceitos fundamentais para a boa convivência, aliados à exacerbação do desejo de ter, consumir e ostentar, têm gerado monstros insensíveis e vorazes.

Grandes corporações estudam como programar a obsolescência de seus produtos, geram expectativas desmedidas e irreais quanto à eficácia de seus lançamentos (muitas vezes meras reedições de fracassos passados) e cooptam profissionais bem conhecidos para ajudar a validá-los e vendê-los.

A ânsia pela fama, pelo conforto e por contas bancárias muito acima do razoável ajudam a ver com naturalidade tais desfigurações da atividade médica. O respeito pelo semelhante é posto de lado, importando o paciente apenas como objeto de ganho, lícito ou não.

Títulos de pós-graduação e de docência, assim como posições de destaque na classe e na comunidade, são buscados a todo custo por alguns para uso como púlpitos de onde possam bradar sua sapiência "indiscutível” ou escudos contra sanções de qualquer ordem.

Qual a finalidade disso tudo? Será que tal conduta gera felicidade genuína? Sabemos que não. Quase sempre (o tempo tem mostrado de maneira eloquente) o resultado é uma chusma de doenças, desastres (pessoais ou familiares), desgraças de toda ordem e desilusão. Não é o mero acúmulo de bens materiais e/ou de honrarias que produz felicidade.Buscar a paz de espírito, a saúde do corpo e o equilíbrio familiar são receitas milenares, mais simples e tremendamente eficazes. Isso significa exercer a profissão com amor ao semelhante, solidariedade com os companheiros, moderação na competição e a certeza de que (como dizia Ortega y Gasset) "o homem é apenas metade de si mesmo; a outra é sua circunstância”. Portanto, não há porquê desesperar-se por não pertencer ao clube dos famosos, não ostentar o título de professor de alguma Universidade importante, não ser a estrela dos congressos. Nem todos são bafejados com circunstâncias favoráveis à notoriedade.

Não se trata de fazer apologia da mediocridade. Antes, pretendemos estimular os colegas a ver com alegria as vitórias (quando merecidas) de seus pares. "Se você não pode ser um pinheiro da montanha seja a relva do vale, mas seja a relva mais verdejante", escreveu o poeta. E diante do sucesso imerecido lembremo-nos que, pior do que sofrer injustiças é praticá-las.

Sobretudo, mantenhamos sempre viva a idéia da transitoriedade da vida, aliada à outra de que estamos aqui para servir. Em nossa profissão isso significa ter o doente como preocupação máxima 
- como preceitua nosso Código de Ética - e por ele manter-se atualizado, conhecer os próprios limites e refrear a ambição desmedida por cifrões.

A prática desses conceitos resultará, com toda a certeza, em vida agradável e consciência tranquila. E será nosso maior legado aos descendentes, por mais desprestigiada que esteja a ética nos dias que correm.

Francisco Valter da Justa Freitas Oftalmologista do Centro Visual do Ceará 